\title{
Chevron and the Canon Favoring Indians
}

\author{
Peter S. Heinecke†
}

Since 1832, a basic tenet of Indian law has been that courts should interpret ambiguous treaties and statutes in favor of Native Americans. ${ }^{1}$ This canon is rooted in the notion of a wardship relation between the U.S. government and the Native American tribes which courts are bound to protect and foster. ${ }^{2}$ Over the years, the canon has consistently protected Native Americans' rights from infringement by states, individuals, and the executive branch. The Supreme Court's decision in Chevron v Natural Resources Defense Council, ${ }^{3}$ however, raises the question of whether courts should invoke the canon to invalidate agencies' interpretations of the laws they administer.

Chevron creates a presumption that courts should defer to an agency's interpretation of an ambiguous statute. Already, government agencies exert a tremendous degree of control over the life of most Native Americans-particularly those living on reservations. ${ }^{5}$ If courts strictly follow Cheuron, those Native Americans will lose a valuable source of protection from governmental caprice and bias. But implicit in Cheuron's grant of deference to administrative agencies is an acceptance of the risk of agency caprice, bias, and error. Application of the canon favoring Indians thus cannot be

\footnotetext{
$\dagger$ A.B 1987, Princeton University; J.D. and M.B.A. candidate 1994, The University of Chicago.

1 See Worcester $v$ Georgia, 31 US (6 Pet) 515, 582 (1832) (McClean concurring) ("The language used in treaties with the Indians should never be construed to their prejudice.").

${ }^{2}$ See id at 555 (describing the relationship between the Cherokee Nation and the United States as "that of a nation claiming and receiving the protection of one more powerful").

367 US 837 (1984).

- See id at 843.

- Until the 1930s, almost all federal legislation relating to Native Americans was administered by the Bureau of Indian Affairs. Since then, administration of Native American matters has been dispersed throughout the federal government. Currently, at least nine cabinet level departments and ten individual agencies administer programs relating to Native Americans. These include the Department of Health and Human Services, the Department of Agriculture, the Department of the Interior, and the Department of Housing and Urban Development. For a comprehensive description of federal laws and bureaucracies which affect Native Americans, see Felix S. Cohen, Handbook of Federal Indian Law 188-206 (Michie Bobbs-Merril, 1982).
} 
justified merely by a desire to protect Native Americans from agency abuse; rather, it can only be applied to the extent it is consistent with the presumptions underlying Chevron.

Two circuit courts of appeals have considered the issue of whether the canon or Chevron deference should prevail when the two doctrines conflict. The Ninth Circuit has concluded that the canon is merely a guideline, and therefore courts should defer to agency interpretations. ${ }^{6}$ The D.C. Circuit has reached the opposite conclusion, by examining the canon in light of its origins as an equitable doctrine. ${ }^{7}$ This Comment first argues that neither of these courts has provided a fully adequate explanation for its position, and then subjects this doctrinal conflict to more exacting analysis.

This Comment approaches the conflict between Chevron and the canon by examining and comparing the history, evolution, and principles underlying both doctrines. Section I analyzes the reasons why the Chevron Court shifted to a policy of deference and looks at some possible limitations on that policy. Noting that Chevron explicitly supports the application of canons of construction, but arguing that the application of some canons is inconsistent with Cheuron, Section I concludes that the application of any particular canon must be justified in light of the presumptions underlying Chevron. Section II explores the origins of the canon favoring Indians and finds it rooted in a broad notion of a wardship relation between the United States and Native Americans. In particular, it focuses on the way courts have used the canon to protect and foster that relation. Section III examines the interaction of the doctrines and concludes that judicial application of the canon is consistent with the factors motivating Cheuron deference and will best protect the values underlying the canon.

\section{The Chevron Doctrine}

The Chevron decision represents a major shift in the relationship between the judiciary and administrative agencies. By deciding to defer to agency interpretations of ambiguous statutes, Chevron effectively increases the amount of power delegated to those agencies. As discussed below, Chevron does not require courts to defer to agencies in all cases. Instead, the reasoning of Chevron suggests that the Court was merely creating a presumption of dele-

\footnotetext{
- Shields v United States, 698 F2d 987, 990 (9th Cir 1983).

7 Albuquerque Indian Rights v Lujan, 930 F2d 49, 59 (DC Cir 1991); Muscogee (Creek) Nation v Hodel, 851 F2d 1439, 1444-45 (DC Cir 1988).
} 
gation, a presumption that Congress had delegated authority to the agency. Subsequent Supreme Court opinions support this interpretation of the case, as do the exigencies of the administrative state. $^{8}$

Since Cheuron, the Court has not abandoned its review of all administrative interpretations of ambiguous statutes. ${ }^{\theta}$ The presumption that Congress has delegated power is rebuttable. In particular, the Court has applied canons of statutory construction to determine the meaning of statutes or to narrow the extent of delegation. ${ }^{10}$ The application of such canons is, in general, consistent with Chevron.11 Nevertheless, the application of any particular canon must be examined to determine whether that application is consistent with the reasons underlying the presumption of delegation.

\section{A. The Cheuron Decision}

In Chevron, the Supreme Court laid out a two-step process for courts to follow when evaluating an agency's interpretation of a statute. The reviewing court should first ask "whether Congress has directly spoken to the precise question at issue."12 If Congress's intent is clear, "that is the end of the matter; for the court, as well as the agency, must give effect to the unambiguously expressed intent of Congress." 13 If Congress has not addressed the precise question at issue, "the question for the court is whether the agency's answer is based on a permissible construction of the statute."14 This two-step process was the key innovation of Cheuron. While the Court had often stated that agency interpretations de-

- See, for example, Young $v$ Community Nutrition Institute, 476 US 974, 981-82 (1986); Sullivan v Everhart, 494 US 83, 94 (1990); Adams Fruit Company v Barrett, 494 US 638 (1990).

- See, for example, Maislin Industries v Primary Steel, Inc., 497 US 116, 131 (1990) (overruling the Interstate Commerce Commission's interpretation of "reasonable" rates and practices as used in the Interstate Commerce Act, 49 USC \& 10701(a) (1988)); Dole $v$ United Steelworkers, 494 US 26, $41-43$ (1990) (overruling the Office of Management and Budget's interpretation of "collection of information" as used in the Paperwork Reduction Act, 44 USC §§ 3502(4), 3507 (1988)).

${ }^{10}$ See, for example, DeBartolo Corp. $v$ Florida Gulf Coast Trades Council, 485 US 568, 575 (1988). See also text accompanying notes 52-54.

"See text accompanying notes $43-45$.

12467 US at 842.

1s Id at 842-43.

14 Id at 843 . 
serve deferential review, ${ }^{15}$ it had never before laid out a process for courts to follow in all instances. ${ }^{16}$

The Court gave three justifications for its decision. First, agencies have greater expertise. ${ }^{17}$ According to the Court, much legislation, like the statute in Cheuron itself, is highly technical and complex. An agency has the time and the resources to examine the statute and apply it in a reasoned manner. Furthermore, statutes often conflict and interact. An agency which oversees a large body of law is best able to minimize conflict and ensure that the different statutes interact properly. ${ }^{18}$

Second, agencies are politically accountable. ${ }^{19}$ According to the Court, decisions in these cases often involve political considerations, and agencies, through the Chief Executive, are accountable to the people. ${ }^{20}$ If Congress itself, for some reason, declined to make the political decision, a branch which is accountable should. ${ }^{21}$

Third, courts have a very limited role to play in making political decisions. According to the Court, the Constitution vests the responsibility for "assessing the wisdom of . . . policy choices and resolving the struggle between competing views of the public interest" in the political branches. ${ }^{22}$ Implicit in this justification is the idea that certain ambiguities can be resolved only by reference to political values, not legal tools.

\section{B. Criticism of Cheuron}

None of these three factors justifies mandatory deference to agencies. None explains why, at a theoretical level, courts must limit their power of review over agency action.

Agencies do have greater expertise than the courts, but the Constitution entrusts courts with ultimate responsibility for interpreting the law. ${ }^{23}$ In the context of interpretation, agencies rank below courts in the hierarchy, and competence cannot override the

\footnotetext{
${ }^{25}$ Laurence H. Silberman, Chevron-The Intersection of Law \& Policy, 58 Geo Wash L Rev 821, 822-25 (1990).

10 Robert A. Anthony, Which Agency Interpretations Should Bind Citizens and the Courts?, 7 Yale J Reg 1, 6 (1990).

17467 US at 865.

18 Id.

19 Id.

$20 \mathrm{Id}$.

21 Id.

22 Id at 866.

23 Marbury v Madison, 5 US (1 Cranch) 137, 177 (1803).
} 
constitutional structure. As Justice Scalia has noted, even if there were an appellate judge clearly more able than he (Scalia gives the example of Learned Hand), Scalia would still have the power to review the judge's decision..$^{24}$

There is also an inherent tension in using both agency expertise and political accountability to justify deference. Agency expertise implies a technocratic search for the best answer, while political accountability implies a search for the most popular answer. The two answers will often be different, and it is not clear on a theoretical level which consideration should prevail..25

Furthermore, courts often and unavoidably make political judgments. If a court faces the question posed in Cheuron without the benefit of an agency interpretation, it still must resolve the question. In such cases, most courts would probably follow a procedure similar to that used by the D.C. Circuit in Cheuron itself; they would look to the purpose of the statute, even if doing so required them to make a political judgment. ${ }^{28}$ Indeed, the Court in Chevron recognized that it sometimes has to "reconcile competing political interests." ${ }^{27}$ Nevertheless, it believed that agencies were better equipped than courts to make those decisions. ${ }^{28}$ Ultimately, it appears that its position was motivated more by prudence than by adherence to the doctrine of separation of powers.

Because Chevron gives agencies a tremendous-and for some a worrisome-amount of autonomy, many commentators have suggested ways of limiting its scope. ${ }^{29}$ Some commentators have taken the position that the factors discussed above-the expertise and political accountability of agencies and the limited role of the courts in answering political questions-are limiting rather than explanatory factors. ${ }^{30}$ Under this view, courts should defer when a question is very technical or politically contentious, but not when

24 Antonin Scalia, Judicial Deference to Administrative Interpretations of Law, 1989 Duke L J 511, 514.

${ }^{25}$ See Sanford N. Caust-Ellenbogen, Blank Checks: Restoring the Balance of Powers in the Post-Chevron Era, 32 BC L Rev 757, 814 (1991) ("[A]lthough majoritarian concerns influenced the Constitution, the structure of government involves a balance of majoritarian and non-majoritarian practices and institutions . ...").

${ }^{26}$ See Natural Resources Defense Council v Gorsuch, 685 F2d 718, 726-27 (DC Cir 1982); Scalia, 1989 Duke L J at 515-16.

${ }_{27} 467$ US at 865.

${ }^{28} \mathrm{Id}$.

20 See Caust-Ellenbogen, 32 BC L Rev at 823-27; Stephen G. Breyer, Judicial Review of Questions of Law and Policy, 38 Admin L Rev 363, 376-82 (1986).

so See, for example, Caust-Ellenbogen, 32 BC L Rev at 823-27; Breyer, 38 Admin L Rev at $376-77$. 
agency interpretations raise constitutional or procedural issues or concerns of agency bias. ${ }^{31}$

The problem with these approaches is that they essentially revert to a pre-Chevron world. Before Chevron, the Court's approach to review was not entirely coherent, but it did follow a pattern. In general, courts would carefully examine each case in an attempt to determine whether or not Congress intended to delegate power to the agency in question..$^{32}$ To make these determinations, courts looked to factors similar to the ones discussed in Chevron, to legislative history, and to other considerations. This case-by-case approach resulted in an unwieldy jurisprudence which produced unpredictable results. ${ }^{33}$

\section{An Explanation for Chevron}

Cheuron is best understood as a departure from the prior caseby-case approach. Instead of attempting to determine Congress's intent on a case-by-case basis, the Court assumed that ambiguity meant Congress intended to delegate power and the Court should therefore defer to the agency's interpretation..$^{34}$

Under this view, the reasons the Chevron Court gives for deference support a presumption of delegation. Congress may have wanted the benefit of agency expertise, or it may have wanted the decision to be made by a politically accountable body, ${ }^{35}$ or it may have thought that judicial tools would not be useful in resolving potential conflicts. Under Chevron, courts are no longer required to isolate one of these reasons for deference. Instead, in any instance of ambiguity, they effectively assume that one exists and automatically defer. Nevertheless, the reasons are important because, as is discussed in subsection $\mathrm{D}$, they suggest some broad areas where the presumption of delegation does not apply.

${ }^{31}$ Note, Coring the Seedless Grape: A Reinterpretation of Chevron U.S.A. Inc. v. NRDC, 87 Colum L Rev 986, 1002-07 (1987).

${ }^{32}$ See Anthony, 7 Yale J Reg at 12 (cited in note 16). See also Scalia, 1989 Duke L J at 515-16.

ss Anthony, 7 Yale J Reg at 6.

34 467 US at 844 ("Sometimes the legislative delegation to an agency on a particular question is implicit rather than explicit. In such a case, a court may not substitute its own construction of a statutory provision for a reasonable interpretation made by the administrator of an agency."). See Cass R. Sunstein, Law and Administration After Chevron, 90 Colum L Rev 2071, 2090 (1990) (describing the Chevron approach as "the best reconstruction of legislative instructions on the question of deference").

ss The notion of political accountability is very close to the notion of legitimacy, which some commentators have argued is the primary motivation for Chevron. See Silberman, 58 Geo Wash L Rev at 823-24 (cited in note 15). 
When applied case by case, the presumption of delegation will not always be correct. When it enacts a bill, Congress may sometimes expect courts to review agency actions closely. Ambiguity is not the same thing as delegation. ${ }^{36}$ Nevertheless, the presumption is a reasonable one considering the role of the administrative state today. ${ }^{37}$ Given the tremendous scope and complexity of federal regulation, Congress may well believe that agencies are best situated to provide interpretations. Given the volume of regulation and the limited capacity of the courts, Congress cannot possibly expect courts to review every agency determination de novo. To a great extent, Congress must rely on the agencies rather than the courts to implement the law uniformly. ${ }^{38}$ Furthermore, discerning Congress's intent is a difficult task. Presuming that Congress intended to delegate power is likely to be as accurate as actually conducting the inquiry. ${ }^{39}$

There are many possible interpretations of Chevron, and the Court has not explicitly adopted any one of them. Nevertheless, the Court does appear to have adopted a general presumption that ambiguity means delegation. ${ }^{40}$ As it noted in Adams Fruit Co. $v$ Barrett, "[a] precondition to deference under Cheuron is a congressional delegation of administrative authority."41 Furthermore, the Court no longer determines on a case-by-case basis whether Congress intended to defer, and it has made no effort to limit deference to those cases in which the motivating factors are present or by any of the other schemes suggested by commentators. As is discussed below, the Court has, however, been willing to use canons of

so Sunstein, 90 Colum $L$ Rev at 2090 ("To be sure, such a reconstruction would not track legislative desires under every statute. By itself, an ambiguity is not a delegation of law-interpreting power.").

${ }^{37}$ Scalia, 1989 Duke L J at 516-17 (cited in note 24).

so See Peter L. Strauss, One Hundred Fifty Cases per Year: Some Implications of the Supreme Court's Limited Resources for Judicial Review of Agency Action, 87 Colum L Rev 1093,1121 (1987) ("By removing the responsibility for precision from the courts of appeals, the Chevron rule subdues this diversity, and thus enhances the probability of uniform national administration of the laws.").

3" Scalia, 1989 Duke L J at 517.

40 The Court did, however, depart from this presumption in INS v Cardoza-Fonseca, when it held that no deference was due when the question presented was purely one of statutory construction. 480 US 421, 446-47 (1987). Since Cardoza-Fonseca, the Court has not again advanced that theory, and in NLRB $v$ United Food and Commercial Workers Union, four justices argued that the Cardoza-Fonseca approach had been repudiated. 484 US 112, 133-34 (1987) (Scalia concurring).

11494 US 638, 649 (1990). 
construction to rebut the presumption of congressional delegation. ${ }^{42}$

\section{Canons of Statutory Construction}

Chevron explicitly states that courts should apply traditional canons of statutory construction in determining whether or not a statute is ambiguous. ${ }^{43}$ Because the traditional canons provide quite an arsenal of interpretative power, courts could, in theory, nullify Chevron's presumption of delegation by always finding a meaning in a statute. Their ability to subvert Chevron in this way is limited in part by the definition of ambiguity. As Justice Scalia has noted, the opposite of ambiguity is "clarity," and not "resolvability."44 Courts must find that Congress has spoken to the specific question at issue-not merely that they can produce a good argument for one interpretation of the statute. ${ }^{45}$

In addition, the application of some canons is not consistent with Chevron. In general, canons of construction are assumed to effectuate congressional intent by protecting certain values. ${ }^{48}$ Chevron marks a significant change in what the Court considers to be congressional intent. ${ }^{47}$ In some instances, this new conception of intent indicates that judicial application of a canon is not the best way of protecting the values embodied in the canon.

Before applying a canon, a court should determine if its application is consistent with the Court's post-Chevron presumptions concerning congressional intent. ${ }^{48}$ Consider, for example, the oftinvoked syntactic canons: text-based canons that reveal the "plain meaning" of a statute. ${ }^{49}$ Application of these canons is consistent with the presumption of delegation. These canons are widely

12 See DeBartolo Corp. v Florida Gulf Coast Trades Council, 485 US 568, $574-75$ (1988) (canon holding that statutes should be interpreted to avoid constitutional difficulties); EEOC v Arabian American Oil Co., 111 S Ct 1227, 1230, 1235 (1991) (presumption against extraterritorial application of statutes); Bowen $v$ Georgetown University Hospital, 488 US 204, 208, 212 (1988) (presumption against retroactive rulemaking).

43467 US at $843 \mathrm{n} 9$.

4 Scalia, 1989 Duke L J at 520 (cited in note 24).

15 Even under this standard, the Court has often split on whether a statute is ambiguous. See, for example, Pauley v Bethenergy Mines, Inc., $111 \mathrm{~S} \mathrm{Ct}$ 2524, 2534, 2539 (1991).

${ }^{46}$ See, for example, Bowen, 488 US at 208-09; DeBartolo, 485 US at 575; Choate v Trapp, 224 US 665, 675 (1912).

${ }^{12}$ See text accompanying notes 34-39.

18 This approach is distinct from the Court's pre-Cheuron approach. A court need not determine Congress's intent for each statute. Rather, it must determine whether a canon is consistent with the Court's presumptions about Congress's intent. This determination needs to be made only once for each canon.

12 See Sunstein, 90 Colum L Rev at 2106 (cited in note 34). 
known and accepted, and Congress probably expects that legislation will be interpreted in light of them. None of the factors supporting the presumption of delegation-the expertise and political accountability of agencies and the limited role of the courts in answering political questions-would suggest that the courts should not apply syntactic canons; indeed, the judiciary's particular skill in applying them argues just the opposite.

In contrast, courts reviewing agency determinations of ambiguous statutes should not apply the canon that nullifies "absurd" results. ${ }^{\text {so }}$ Undoubtedly, Congress does not want legislation to cause absurd or irrational results, but it would be inconsistent with Chevron to believe that the courts, as opposed to the agencies, should protect against those results. One of the motivating factors behind Cheuron deference is that agencies have greater expertise; they presumably know better than courts what constitutes an "absurd" result. Courts, therefore, should not overturn an agency interpretation on the grounds of absurdity-so long as it is a reasonable interpretation of a statute.

Determining whether or not a court should apply statutory canons that have a substantive purpose presents greater difficulties. These canons include reading statutes so that they do not intrude on constitutional rights, disfavoring of retroactive application of statutes, and the canon favoring Indians. These canons are often based on policy considerations; therefore, judicial deference might be most appropriate. When confronting these cases, the Court has often justified the application of these canons by arguing that they accord with congressional intent..1

In DeBartolo Corp. $v$ Florida Gulf Coast Trades Council, ${ }^{\mathrm{s2}}$ the Court reviewed a National Labor Relations Board ruling that prohibited distributing handbills at shopping malls under certain circumstances. While Chevron dictated that the Court should defer to the NLRB's interpretation of the National Labor Relations Act, the canon holding that statutes be interpreted so as to avoid constitutional difficulties urged otherwise. ${ }^{53}$ Since reading the NLRA so as not to authorize the NLRB's action would avoid a First Amendment problem, the Court gave it that construction. ${ }^{54} \mathrm{De}$ spite appearances, this result is consistent with Chevron. As with

so See, for example, Holy Trinity Church v United States, 143 US 457, 459-60 (1892).

s1 See, for example, Bowen, 488 US at 208-09.

${ }^{62} 485$ US 568 (1988).

ss Id at 575 .

st Id at 588. 
the syntactic canons, an analysis of this canon in light of the factors motivating deference suggests that application of the canon is appropriate. Courts are better suited than agencies to interpret the Constitution and have a special duty to protect it. Here the political accountability of agencies may well be an argument against the delegation of power.

By way of contrast, courts should not apply the canon that antitrust exemptions should be interpreted narrowly. Antitrust law is designed to protect the economy from the dangers of monopoly. Determining the economic effect of any particular business combination or practice is complex and rather fact-specific. If Congress grants an exemption to the antitrust laws, it may have only a general goal in mind-ensuring that cities have at least two newspapers with independent editorial boards, for example. ${ }^{55}$ While courts are certainly capable of dealing with antitrust cases, Cheuron presumes that agencies are likely to be even better at resolving such complex, fact-specific disputes. As the democratic process is generally considered a legitimate way of resolving disputes over economic policy, the political accountability of agencies argues in their favor. In any case, none of the factors motivating Cheuron deference suggest that Congress would not want to delegate antitrust authority to agencies; courts, therefore, should defer.

\section{E. Summary}

Canons of statutory construction are useful tools for analyzing legislation. Under Cheuron, courts should use them to resolve ambiguities in statutes. However, at times application of the canons will be inconsistent with Chevron. Underlying Chevron is the presumption that Congress has delegated power to an agency because it is more competent, because it is more accountable, or because the judiciary's special skills are not needed. This new conception of congressional intent raises the possibility that the values underlying canons can be better protected by agencies than by courts. A court, therefore, should invoke a canon only if, after considering the factors motivating Chevron deference, it concludes that judicial application of the canon is still the best way to protect the values underlying the canon.

${ }^{s}$ See Michigan Citizens for an Independent Press v Thornburgh, 868 F2d 1285 (DC Cir), aff'd, 493 US 38 (1989). 


\section{The Canon Favoring Indians and the Notion of Wardship}

In Cherokee Nation $v$ Georgia ${ }^{56}$ the Supreme Court defined the status of Native Americans in American law. Though the Native Americans lost that dispute, the decision spawned a line of cases that in many instances has treated Native Americans favorably. In Cherokee Nation, the Court faced the question of whether it had jurisdiction to resolve a dispute between Cherokee living on land within the boundaries of Georgia and the state of Georgia. ${ }^{57}$ While the Court was sympathetic to the Cherokee position-Georgia was enforcing its laws on Cherokee territory to the detriment of the Cherokee Nation ${ }^{58}$ - the Court concluded it did not have original jurisdiction because the Cherokee Nation was not a foreign nation. ${ }^{59}$ The Court conceded that the Cherokee Nation was "a distinct political society," "domestic dependent nations." In an important passage, the Court went on to state that Native American tribes "are in a state of pupilage. Their relation to the United States resembles that of a ward to his guardian." ${ }^{2}$ Thus was born the notion of wardship. Later, in Felix $v$ Patrick, the Court described what this wardship relation entailed: as "wards of the nation," Native Americans were "entitled to a special protection in its courts." thus granted Native Americans "special protection," carefully scrutinizing attempts by individuals, states, and the executive branch to limit the rights of Native Americans. It has recognized, however, that the Constitution gives Congress special powers relating to $\mathrm{Na}$ tive Americans and, therefore, has been more deferential in its review of congressional action. ${ }^{64}$

Several distinct judicial doctrines have emerged since Cherokee Nation. Though commentators sometimes analyze these doctrines separately, their presumptions are similar and the Court has always viewed them as rooted in the wardship relation. For the

so 30 US (5 Pet) 1 (1831).

87 See id at 15-19.

s8 Id at 15.

89 Id at 19. According to Article III, $\S 2$ of the Constitution, as amended by the Eleventh Amendment, the Court has original jurisdiction over controversies between a state and foreign states.

so Id at 15.

61 Id at 16.

as Id.

es 145 US 317,330 (1892).

** See Reid Peyton Chambers, Judicial Enforcement of the Federal Trust Responsibility to Indians, 27 Stan L Rev 1213, 1224-27 (1975). 
purposes of this Comment, the two most important doctrines are the canon favoring Indians and the trust doctrine. The canon favoring Indians holds that courts should interpret ambiguous treaties and statutes broadly in favor of Native Americans. ${ }^{.65}$ The trust doctrine applies the notion of Native Americans as wards literally. It holds that the government has a strict fiduciary duty toward Native Americans, a duty which goes beyond merely acting in good faith. ${ }^{B 6}$ An analysis of these two doctrines sheds light on the principles underlying the notion of wardship. Understanding those principles is critical to determining whether judicial application of the canon favoring Indians is consistent with the factors motivating the presumption of delegation.

\section{A. The Evolution of the Canon Favoring Indians}

The Court first enunciated the canon favoring Indians in Worcester $v$ Georgia. ${ }^{67}$ In Worcester, as in Cherokee Nation, Georgia was trying to apply its laws in Native American territory to the detriment of Native Americans. Georgia justified this action on the grounds that in the Treaty of Hopewell the Cherokee had surrendered their sovereignty and had ceased to be a distinct political community. One part of Georgia's argument was that the treaty spoke of Cherokee territory as being "allotted," which implies that it was being given. to the Cherokee by the United States, as opposed to being "marked out," which would be more consistent with the notion of a boundary being drawn between two political entities. ${ }^{88}$ Chief Justice Marshall rejected this argument. He held that it was not "reasonable to suppose, that the Indians, who could not write and most probably could not read, who certainly were not critical judges of our language, should distinguish the word 'allotted' from the words 'marked out." "'89 In a concurrence, Justice McClean provided the classic formulation of the canon: "The language used in treaties with Indians should never be construed to their prejudice. . . . How the words of the treaty were understood by this unlettered people, rather than their critical meaning, should form the rule of construction."

${ }^{8 s}$ See Choate $v$ Trapp, 224 US 665, 675 (1912).

${ }^{68}$ See United States v Kagama, 118 US 375, 383-84 (1886).

${ }^{67} 31$ US (6 Pet) 515 (1832).

${ }^{8 s}$ Id at 552.

"s Id.

${ }^{70}$ Id at 582 (McClean concurring). 
In rejecting Georgia's argument, Justice Marshall objected not only to Georgia's inequitable reading of the treaty but also to its interference with the relationship between the federal government and the Native Americans. He noted that the United States, in its treaties with the Cherokee, had solemnly pledged "to restrain their citizens from trespassing" on Native American lands. ${ }^{71}$ The Court held that Georgia's action interfered with this pledge and with congressional legislation giving effect to the treaties. ${ }^{72}$ Worcester is the first in a line of cases where the Court intervened to protect Native Americans from states' attempts to construe congressionally granted rights narrowly. ${ }^{73}$

In Choate $v$ Trapp, ${ }^{74}$ the Court strengthened the canon favoring Indians. In Choate, the Court faced the question of whether certain lands previously owned by Native Americans were tax-exempt. ${ }^{75}$ By statute, Congress had allocated to the Native Americans certain lands and granted them a tax exemption with the proviso that the lands could not be alienated for a period of years. ${ }^{78}$ Subsequently, Congress removed the restriction on alienation. ${ }^{77}$ Oklahoma attempted to tax the lands, arguing that, with the removal of the restriction on alienation, Congress must have intended to end the tax exemption. ${ }^{78}$ The Court noted that, under general rules of statutory construction, the state would win because tax exemptions are to be construed narrowly. ${ }^{79}$ However, "in the Government's dealings with Indians the rule is exactly the contrary . . . doubtful expressions, instead of being resolved in favor of the United States, are to be resolved in favor of a weak and defenseless people, who are wards of the nation, and dependent wholly upon its protection and good faith."

Choate is significant for a number of reasons. First, it reemphasized that the canon favoring Indians is ultimately rooted in

71 Id at 561 .

72 Id at 561-62.

7s See Choate, 224 US at 675; Montana v Blackfeet Tribe of Indians, 471 US 759, 766 (1985).

${ }^{74} 224$ US 665 (1912).

75 See id at 667.

36 Id at 668-69. The statute, the Curtis Act, 30 Stat 505 (1898), enacted as legislation the Atoka Agreement between the federal government and the Choctaw and Chickasaw tribes.

${ }^{77}$ Act of May 27, 1908, 35 Stat 312, codified at 25 USC $\S 355$ (1988). See Choate, 224 US at 670 .

78 Choate, 224 US at 672.

79 Id at 674-75.

so Id at 675 . 
the notion of wardship. Second, for the first time the Court applied the canon to a statute rather than a treaty. Although in Choate the statute actually embodied a negotiated agreement between the government and the Native Americans, ${ }^{81}$ the Court has ignored this feature of Choate in subsequent cases. ${ }^{82}$ Third, the Court applied the canon favoring Indians to the exclusion of the canon on taxation, which would have directed a contrary result. Finally, the Court justified its application of the rule by referring to congressional intent. It stated: "In view of the universality of [the canon], Congress is conclusively presumed to have intended that the legislation under which these allotments were made to the Indians should be liberally construed ...."\$3

The Court developed the Choate approach further in Alaska Pacific Fisheries $v$ United States. ${ }^{84}$ In Alaska Pacific Fisheries, the Court determined the extent of a land grant Congress had made to certain Native Americans. ${ }^{85}$ Around 1887, a band of Metlakahtlans migrated to Alaska and settled on a group of islands off its coast. ${ }^{86}$ Congress subsequently granted the islands to the Metlakahtlans. ${ }^{87}$ In 1916, Alaska Pacific Fisheries began fishing for salmon in the channels between the islands. ${ }^{88}$ The company's advanced techniques threatened to diminish the salmon population and destroy the Metlakahtlans' livelihood. ${ }^{89}$ The United States sought to enjoin the company from fishing, arguing that Congress had granted the Metlakahtlans dominion not only over the islands but also over the channels between them. ${ }^{90}$ The Court, citing Choate, held that the grant should be broadly construed. ${ }^{91}$ It buttressed this holding by noting that Congress, acting as guardian, would not have provided the Metlakahtlans with a reservation un-

81 In 1871, Congress passed a law denying the President treaty-making power with Native Americans. See Act of March 3, 1871, 16 Stat 566, codified at 25 USC $\S 71$ (1988). Though the constitutionality of this act is dubious, all further agreements between the United States and Native Americans became law as legislation enacted by Congress, rather than as treaties approved by the Senate. See William C. Canby, Jr., American Indian Law in A Nutshell 79-80 (West, 1981).

S2 See Alaska Pacific Fisheries v United States, 248 US 78, 89 (1918).

83 Choate, 224 US at 675.

248 US 78 (1918).

8s Id at 89.

se Id at 86 .

87 Act of March 3, 1891, 26 Stat 1101, codified at 25 USC $\S 495$ (1988). See Alaska Pacific Fisheries, 248 US at 86-87.

8824 US at 87.

s9 Id at 87-88.

so Id at 86-87.

91 Id at 89 . 
less the grant would allow them to be self-sufficient. ${ }^{92}$ This is one of several cases where the Court used the idea of guardianship to elucidate the intent of Congress. ${ }^{93}$

The Court has applied the canon even where the legislation in question was not necessarily designed to benefit Native Americans. In 1953, in response to increasing crime on some reservations, Congress removed the shield of Indian sovereignty from those lands and allowed state law to apply. ${ }^{94}$ In Bryan v Itasca County, ${ }^{95}$ the Court considered whether this legislation authorized the states to tax the lands. In construing the statute's ambiguous language, the Court followed Choate and held that the repeal of sovereignty allowed the application of only civil and criminal laws and not taxing authority. ${ }^{96}$

The only case in which the Court has expressly not applied the canon is Montana $v$ United States. ${ }^{97}$ At issue there was whether a federal land grant to the Crow included a grant of the bed of the Big Horn River. ${ }^{98}$ The Court had to choose between applying the canon favoring Indians and another canon which held that federal land grants were presumed not to include beds of navigable rivers. ${ }^{99}$ The Court construed the grant narrowly, arguing that when the grant was made, no purpose would have been served by granting the bed to the Native Americans, and therefore Congress presumably followed the normal course of retaining federal ownership. ${ }^{100}$

As the above discussion indicates, the canon favoring Indians is a well-established canon rooted in the notion of a wardship relation between the United States and Native American tribes. In general, the Court has applied the canon broadly and has failed to apply it only when its application was inconsistent with the purposes of the wardship.

92 Id.

os See, for example, Winters $v$ United States, 207 US 564, 576-77 (1908); Cramer $v$ United States, 261 US 219, 232 (1923); McClanahcn v Arizona State Tax Commission, 411 US 164, 174-75 (1972).

Act of Aug 15, 1953, Pub L No 280, 67 Stat 589, codified at 28 USC § 1360 (1988).

os 426 US 373 (1976).

96 Id at 392 .

97 450 US 544 (1981).

9s Id at 547.

90 See id at 552.

${ }^{100}$ Id at 556-57. In contrast, in Winters $v$ United States, 207 US at 575-77, the Court interpreted a grant to include water rights because such rights were essential to the tribe's survival. See also Alaska Pacific Fisheries, 248 US at 89 (construing a land grant of islands to include surrounding waters because resident Indians clearly depended on fishing in them); text accompanying notes 84-93. 


\section{B. The Trust Doctrine}

Like the canon favoring Indians, the trust doctrine originates in the wardship relation between the United States and Native American tribes. The trust doctrine, however, covers a different facet of this relationship. Rather than supplying an interpretative principle for the Court, the trust doctrine defines the powers and responsibilities that accrue to Congress and the executive branch as a result of the wardship relation.

In United States $v$ Kagama, the Court upheld a federal statute that applied federal criminal law to certain crimes that occurred on Native American territory. ${ }^{101}$ The Court concluded that the power of Congress to enact such regulations was not derived from its constitutionally granted powers to regulate commerce but rather from the relationship between the tribes and the United States. ${ }^{102}$ It stated, "[ $\left.t\right]$ hese Indian tribes are the wards of the nation. . . . From their very weakness and helplessness . . . there arises the duty of protection, and with it the power."103

The wardship relation gives Congress not only the power to protect Native Americans but also the power to control their land and liberties. In Lone Wolf $v$ Hitchcock, the Court declared that Congress, as guardian, had "plenary" power to manage Native American property. ${ }^{104}$ The case involved an act of Congress that authorized the distribution of communal lands to individual $\mathrm{Na}$ tive Americans as well as the sale of certain unused lands. ${ }^{105} \mathrm{Mem}-$ bers of the tribe sued, arguing that Congress had violated an 1867 treaty. ${ }^{108}$ The Court held that the treaty did not "materially limit ... the controlling authority of Congress in respect to the care and protection of the Indians."107 The only obligation placed on Congress was one of acting in "good faith."108

With regard to the executive branch, the Court has been much stricter. In Seminole Nation v United States, the Court held that individual tribe members could recover government payments embezzled by tribe leaders if the individuals could prove the government was aware of the embezzlement when it distributed the

\footnotetext{
101118 US 375 (1886).

${ }^{102}$ Id at $378-79,383-84$.

103 Id at 383-84.

104187 US 553, 565, 568 (1903).

105 Id at 559-60.

${ }^{108}$ Id at 564.

107 Id.

${ }^{208}$ Id at 565-66.
} 
funds. ${ }^{109}$ The executive agency in charge of administering the funds argued that it had fulfilled its obligations by paying the leaders. ${ }^{110}$ The Court, however, held that there is a "distinctive obligation of trust incumbent upon the Government in its dealings with these dependent and sometimes exploited people."111 It stated that the executive branch's actions were to be judged by "the most exacting fiduciary standards."112 Similarly, Lane v Pueblo of Santa Rosa held that the Secretary of the Interior did not have the power to sell certain Indian lands. ${ }^{113}$ The Court acknowledged the existence of the wardship relation but stated that the Secretary's action "would not be an exercise of guardianship, but an act of confiscation."114

At times, the Court has allowed rather vague notions of the federal trust responsibility to trump the actions of executive agents. In Cramer $v$ United States, ${ }^{115}$ the Court upheld certain Native Americans' claims to land on which they had settled without any form of title. The Central Pacific Railway Company had originally gained a patent to the land under a statute that authorized grants of large blocks of land. ${ }^{116}$ According to the terms of the grant, the patent did not include parcels in those blocks that were "occupied by homestead settlers . . . or otherwise disposed of."112 The Court noted that one element of the federal wardship was a policy of encouraging Native Americans to "abandon their nomadic habits,"118 and that allowing the Native Americans to keep the land would advance that policy. ${ }^{119}$ It therefore concluded that the parcel in question was "already disposed of" and that the grant of the patent was not a legitimate exercise of executive authority. ${ }^{120}$

\footnotetext{
${ }^{108} 316$ US 286, 307-08 (1942).

110 Id at 295.

112 Id at 296.

112 Id at 297.

113249 US 110, 113-14 (1919).
}

114 Id at 113. See also Pyramid Lake Paiute Tribe v Morton, 354 F Supp 252 (D DC 1972) There, the court struck down a regulation allowing a federal reclamation project to divert water away from a lake on an Indian reservation. The action violated no statute or treaty but the court held that the Secretary of the Interior was not administering the reclamation statutes in a manner consistent with his role as trustee. See also text accompanying notes 159-62.

115261 US 219, 230 (1923).

118 Id at 224-25.

117 Id at 225.

118 Id at 232 .

210 Id at 230 .

120 Id. 
The Court has never defined the exact scope of the federal trust responsibility. In general, the Court has been more deferential toward congressional as opposed to executive action. As the Court noted in Morton $v$ Mancari, Congress has a "unique obligation toward Native Americans." ${ }^{21}$ But the Court has repeatedly struck down executive actions that infringe on Native American rights or that do not live up to a strict fiduciary standard.

The dichotomy between the Court's treatment of congressional action and executive action illustrates one of the central features of the wardship relation. Though the Court describes the relation as being between the United States and Native Americans, in practice, the court treats it as being between Congress and $\mathrm{Na-}$ tive Americans. The Court has allowed Congress tremendous latitude in its dealings with Native Americans; nevertheless, once Congress has acted, the Court assumes Congress was acting as a guardian. The Court then interprets Congress's actions in the manner most favorable to Native Americans, via the canon. In contrast, the Court has treated the executive branch (along with states and individuals) as a potential enemy of the wardship relation and subjects its actions to more exacting scrutiny.

\section{Comparing Chevron and the Canon Favoring Indians}

The two circuits that have considered the interaction of Chevron principles and the canon favoring Indians have come to different conclusions. The Ninth Circuit, in a series of cases both before and after Cheuron, has concluded that the principle of deference should prevail. The D.C. Circuit, on the other hand, has, in two post-Cheuron cases, been willing to overturn agency interpretations that do not follow the canon. Neither circuit provided particularly detailed reasoning to support its position.

\section{A. The Circuit Court Opinions}

The most recent Ninth Circuit opinion, Haynes $v$ United States ${ }^{122}$ reviewed a decision by the Secretary of the Interior to convey only four acres of land to certain Native Americans rather than the 160 acres that he was permitted to convey under the Alaska Native Claims Settlement Act. The petitioners argued that the statute did not give the Secretary discretion to convey less

121417 US 535, 555 (1974) (upholding a congressionally-mandated affirmative action plan in the Bureau of Indians Affairs).

${ }^{122} 891$ F2d 235, 237 (9th Cir 1989). 
than the full 160 acres. ${ }^{123}$ The court cited Chevron and noted the canon. ${ }^{124}$ It then declined to apply the canon because in a previous case it had not applied it when faced with an interpretation by an agency charged with a statute's administration. ${ }^{125}$ In that case, Shields $v$ United States, ${ }^{128}$ the court gave two reasons for not applying the canon: 1) "the canon is but a guideline and not a substantive law"127 and 2) extended administrative practice deserves judicial deference. ${ }^{128}$

The first reason is exceedingly unpersuasive. The canon is not substantive law, but it is certainly more than a guideline. As discussed in Section II, the Supreme Court has consistently applied it against the executive branch and others in a wide variety of situations. ${ }^{129}$ In some cases, the canon has trumped other canons which might have resolved the case. ${ }^{130}$ To describe it as a mere guideline greatly understates its force in American law. The second argument, though more forceful, is not directed specifically at the canon favoring Indians. It essentially imposes a statute of limitations on challenging an agency's interpretation. This general contention may or may not be true, but an analysis of it would reveal little about the conflict between Chevron and the canon favoring Indians.

The D.C. Circuit first examined the conflict in Muscogee (Creek) Nation $v$ Hodel. ${ }^{131}$ At issue in Muscogee was whether the Oklahoma Indian Welfare Act revived the Creek Nation's right to have tribal courts. ${ }^{132}$ The Bureau of Indian Affairs contended that it did not. ${ }^{133}$ The court concluded that the statute was ambiguous and applied the canon favoring Indians. ${ }^{134}$ The court did not cite Cheuron, but did note that except for the canon, it would have deferred to the agency's interpretation. ${ }^{135}$

123 Id at 239.

124 Id at $238-39$.

125 Id.

128 698 F2d 987 (9th Cir 1983).

127 Id at 990 .

128 Id at 991, citing Assiniboine \& Sioux Tribes v Nordwick, 378 F2d 426, 432 (9th Cir 1967).

120 See, for example, United States $v$ Creek Nation, 295 US 103, 109-10 (1935).

1so See, for example, Montana v Blackfeet Tribe of Indians, 471 US 759, 766 (1985) (the canon favoring Indians trumps the principle of statutory construction disfavoring repeals by implication).

331851 F2d 1439 (DC Cir 1988).

132 Id at 1442.

123 Id.

136 Id at 1444-45.

135 Id at 1445 n 8. 
Subsequently, in Albuquerque Indian Rights $v$ Lujan, ${ }^{138}$ the court cited Muscogee for the proposition that the canon trumps Chevron deference. At issue in the case was whether the Department of the Interior's hiring preference for Native Americans should extend outside the Bureau of Indian Affairs. ${ }^{137}$ The court suggested that in light of the canon favoring Indians the Department should reconsider its decision to apply the preference narrowly. ${ }^{138}$ Countering Haynes, the court offered two reasons the canon should trump Chevron deference. ${ }^{139}$ First, the canon is based on principles of equitable obligations and normative rules of behavior; second, the canon is rooted in the unique trust relationship between Native Americans and the United States. ${ }^{140}$ Both arguments have some merit and are discussed below.

B. Arguments That the Canon Favoring Indians Should Trump Chevron

One commentator has suggested that the canon favoring Indians should trump the Chevron principle because the canon is "designed to require a clear congressional statement before allowing a statute to be interpreted unfavorably to a group that has been mistreated in the past." ${ }^{141}$ Another has argued that the canon can be justified by reference to anti-discrimination principles. ${ }^{142}$ While each of these arguments has some force, both are somewhat ahistorical and in tension with the presumptions supporting Chevron deference.

To begin with, the Court has never construed the canon favoring Indians as a clear statement rule. The presumption of the canon is that Congress administers a wardship over Native Americans. By applying the canon, the Court attempts to promote the purposes of that wardship. Clear statement rules are designed to ensure that explicit congressional authorization is received before some action is taken (for example, before a right is infringed or an

138 930 F2d 49, 59 (DC Cir 1991). Oddly, the court concluded that the plaintiffs did not have standing but then went on to discuss the merits of the dispute. Id at 57, 58-59.

137 Id at 50-51.

183 Id at 58-59.

${ }^{130}$ See id at 59.

140 Id.

141 Sunstein, 90 Colum L Rev at 2115 (cited in note 34).

142 William N. Eskridge, Public Values in Statutory Interpretation, $137 \mathrm{U} \mathrm{Pa} L \mathrm{Rev}$ 1007, 1032-33 (1989). 
entitlement is denied); ${ }^{143}$ in contrast, the canon ensures that congressional designs are advanced. ${ }^{144}$

An anti-discrimination justification is also at odds with the canon's history. The Court was certainly aware that discrimination against Native Americans was a real problem, but the canon was not conceived of as a blanket anti-discrimination provision. The Court has allowed Congress tremendous latitude and has upheld statutes that were very anti-Native American. ${ }^{145}$ If the Court were motivated primarily by anti-discrimination concerns, it would have more vigorously reviewed congressional actions in such instances.

Some commentators have offered the anti-discrimination justification not as an historical argument but as a normative argument. ${ }^{146}$ This defense of the canon has some appeal, but it may be inconsistent with the presumptions of the Cheuron decision. Many other groups besides Native Americans have historically been mistreated by government and society. All of those groups could argue that broad interpretation of statutes in their favor will ensure fair treatment. It may be that because a great deal of legislation is directed solely at Native Americans, they are particularly deserving of special treatment. However, the Constitution does not require a canon favoring Indians (or any other minority). To justify a canon for one group and not for another would require the Court to invoke policy considerations. But one of the presumptions of Chevron is that agencies or elected officials, not courts, should make policy judgments. Thus, an anti-discrimination justification is inconsistent with Cheuron.

\section{The Wardship Relation and the Reasons for Deference}

The best justification for continued judicial application of the canon favoring Indians is based on the canon's origins in the ward-

143 A good example of a clear statement rule is the canon holding that statutes should be interpreted so as not to cause constitutional difficulties. See DeBartolo, 485 US at 575; text accompanying notes 52-54.

144 There are clear statement rules in Indian law. For example, the Court requires a clear statement before assuming that Congress intends to abrogate a treaty with an Indian tribe. See Menominee Tribe of Indians $v$ United States, 391 US 404, 412-13 (1968); Charles Wilkinson and John M. Volkman, Judicial Review of Indian Treaty Abrogation: "As Long as Water Flows, or Grass Grows Upon the Earth"-How Long a Time is That?, 63 Cal L Rev 601, 623 (1975).

145 See, for example, Lone Wolf v Hitchcock, 187 US 553, 561, 563-64 (1903) (upholding statute disposing of lands occupied by Native Americans). See also text accompanying notes 104-08.

168 See Eskridge, $137 \mathrm{U} \mathrm{Pa}$ L Rev at 1047-48; Cass R. Sunstein, Interpreting Statutes in the Regulatory State, 103 Harv L Rev 405, 483-84 (1989). 
ship relation between the United States and Native Americans. In DeBartolo, the Court presumed that Congress would not have wanted to transfer to agencies the power to make decisions which would infringe on constitutional rights. ${ }^{147}$ Similarly, given the history and evolution of the wardship relation, there are good reasons to presume that Congress would not want agencies to have the power to administer any element of the relationship. Before looking at these reasons, it will be useful to examine two arguments suggesting that application of the canon is not appropriate under Chevron.

1. Arguments against the canon.

First, the premises of the canon are arguably no longer valid. As the court in Albuquerque Indian Rights noted, the canon is based on "equitable obligations and normative rules of behavior." 148 The canon was originally applied to treaties negotiated by Native American Chiefs. ${ }^{149}$ A broad interpretation of the treaties offset the disadvantages Native Americans labored under during the negotiations. ${ }^{150}$ Today, courts must interpret statutes enacted by Congress which may or may not reflect any consultation with Native Americans. Application of the canon is arguably purposeless in such instances. Furthermore, to the extent that application is justified by the fact that Native Americans have been inequitably treated in the past, this is the type of policy judgment Chevron indicates should be left to agencies.

Second, agencies may be better than the courts at interpreting these statutes. As discussed in Section II, the statutes can often be best understood once the purposes of Congress are known. ${ }^{151}$ Discerning the goals of Congress and determining which interpretation of a statute will best effectuate those goals are the type of fact-specific inquiries for which agencies are generally well suited. In short, agencies rather than courts may be the best administrators of the wardship relation.

147485 US at 575.

148930 F2d at 59.

149 Worcester, 31 US (6 Pet) at 550 (applied to the Treaty of Hopewell).

${ }^{180}$ See id ("There is the more reason for supposing that the Cherokee chiefs were not very critical judges of the language, from the fact that every one makes his mark; no chief was capable of signing his name.").

${ }^{151}$ See Alaska Pacific Fisheries, 248 US at 87. 
2. Arguments in favor of the canon.

Though strong, the arguments against the canon are not decisive. If, as the first argument suggests, the canon is motivated solely by a desire to compensate Native Americans for an unfair bargaining position, then the canon should be applied only when an agency has interpreted a treaty which was negotiated with $\mathrm{Na}$ tive Americans. As discussed in Section II, the canon must be seen as part of the broader wardship relation. The Court has consistently applied the canon even when there was no indication a statute was the result of bargaining between the government and $\mathrm{Na}$ tive Americans. ${ }^{182}$ Instead, the Court has presumed that when Congress passed a statute it was attempting to fulfill its wardship obligations towards Native Americans and that a broad interpretation would best fulfill that obligation. ${ }^{163}$

Arguably, the canon is outdated because the notion of the wardship relation itself is outdated. Native Americans are no longer in "a state of pupilage" and are not the "unlettered people" they were perceived to be when the wardship relation was enunciated. Nevertheless, the wardship relation still has vitality. ${ }^{154}$ To a greater extent than any other group, Native Americans are dependent on and live their lives controlled by the federal government. The reservation system is a creation of federal law. The Bureau of Indian Affairs and many other agencies administer programs solely for the benefit of Native Americans. While there has been a movement toward giving Native Americans on reservations greater autonomy, the reservations are ultimately under the control of the federal government. Thus while the condition of Native Americans has changed greatly over the last 200 years, they still have a unique relationship with the federal government.

The Court has traditionally described the wardship relation as being between the federal government and Native Americans. In practice, however, it has emphasized Congress's role in guiding the relation. In its application of the canon favoring Indians and the

${ }^{152}$ See, for example, Morton v Mancari, 417 US 535, $551-55$ (1974).

135 See id.

1s The wardship relation is not uncontroversial. Some commentators have argued that it has no basis in the Constitution. Mark Savage, Native Americans and the Constitution: The Original Understanding, 16 Am Indian L Rev 57 (1991). Others have argued that it has been detrimental to Native Americans' economic and social development. Greg Overstreet, Re-empowering the Native American: A Conservative Proposal to Restore Tribal Sovereignty and Self-Reliance to Federal Indian Policy, Hamline J Pub L \& Pol (forthcoming). Nevertheless, the relation remains "one of the primary cornerstones of Indian Law." Cohen, Handbook at 221 (cited in note 5). 
trust doctrine, the Court has demonstrated a deep skepticism of the executive branch's ability to administer the wardship relation properly. ${ }^{165}$ The Cheuron decision represents a change in the Court's assessment of the relative competency and role of the courts, the executive branch, and Congress, and therefore raises the question of whether that skepticism is still justified. As argued below, none of the factors motivating Cheuron indicate that the judiciary should stop using the canon to protect the wardship relation.

Agency competence and political accountability are two of the most important factors motivating Chevron deference. ${ }^{156}$ In the context of Native American affairs, neither of those arguments is particularly strong. Because Native Americans were, and still are, relatively powerless politically, they benefit little from the greater political accountability of the agencies. ${ }^{167}$ Furthermore, because so much of the legislation that affects Native Americans is directed solely at them, they cannot depend on other affected groups to change agency behavior. Agency competence cuts both ways. Agencies may be better able to discern and implement congressional policy, but they may not also give Native American interests sufficient weight. In the administrative state, one of the functions of agencies is to balance competing policy goals. When exercising that function, agencies should give stronger credence to Indian interests: as the Court has repeatedly noted, the executive has strict fiduciary obligations toward Native Americans. ${ }^{108}$ But when faced with competing goals (some of which may be backed by powerful political interests), agencies may well disregard the legitimate claims of Native Americans.

For example, in Pyramid Lake Paiute Tribe of Indians $v$ Morton, the Secretary of the Interior was responsible for developing a plan for allocating the flow of water from the Truckee River in Nevada. ${ }^{169}$ After receiving recommendations from a variety of public and private sources, including the Paiute Indian Tribe, the Secretary issued regulations which would have diverted substantial water away from the Paiute's lake to the Truckee-Carson Irrigation District. ${ }^{160}$ This diversion would have endangered many of the

${ }^{155}$ See text accompanying notes 101-21.

156 See text accompanying notes 17-21.

157 See Nell Jessup Newton, Federal Power Over Indians: Its Sources, Scope, and Limitations, 132 U Pa L Rev 195, 245-47 (1984).

${ }^{158}$ See Chambers, 27 Stan L Rev at 1232-34 (cited in note 64).

150354 F Supp 252, 254 (D DC 1972).

${ }^{160}$ Id at $254,255-56$. 
fish species native to the lake and substantially impaired the utility of the lake. ${ }^{161}$ Citing the wardship doctrine and noting the federal government's fiduciary duty toward Native Americans, the court ruled that the Secretary was required to develop a plan which allowed enough water to flow to the lake to maintain its current condition. ${ }^{162}$ Without the wardship doctrine, the Native Americans' claim would have been just one of many competing claims to the waters of the Truckee River.

Pyramid Lake illustrates the special role assigned to the judiciary under the wardship doctrine. Generally, in the pre-Cheuron era, courts provided an interpretation of an ambiguous statute not because they had any particular interest in the statute itself, but rather because they assumed or determined that Congress had not delegated interpretive power to the agency. In cases involving $\mathrm{Na}$ tive Americans, however, the judiciary's role was different. As the Court noted in Felix $v$ Patrick, the wardship doctrine requires the courts of the United States to provide special protection for Native Americans. ${ }^{163}$ One element of that protection is ensuring the federal government fulfills its fiduciary duty. This role rebuts one of the presumptions underlying the Cheuron approach. Chevron presumes that judicial monitoring of an agency's exercise of delegated power is unnecessary because the judiciary's tools are not particularly useful for resolving ambiguous questions with political overtones. ${ }^{164}$ But in the area of Indian law, that assumption is undercut by the special duty courts have under the wardship doctrine.

The Cheuron approach presumes that Congress has delegated to agencies the power to interpret ambiguous statutes. Because of the special nature of the wardship relation, that presumption is not valid for laws affecting Native Americans. The Chevron presumption is motivated by a belief that agencies are more competent, that they are more accountable, or that judicial monitoring is unnecessary. For Native Americans, however, political accountability is not helpful and agency competency may work against them. Furthermore, a crucial element of the wardship relation is judicial monitoring of the executive. Because the presumption that Congress has delegated power appears implausible, courts should apply the canon favoring Indians when reviewing agency interpretations.

\footnotetext{
${ }^{161} \mathrm{Id}$ at 255.

162 Id at $256-57$.

16s 145 US 317, 330 (1892).

164 See text accompanying notes 19-22.
} 


\section{Application of the Canon Favoring Indians}

Application of the canon will not always be simple. Courts have split on the question of whether canons should be applied to the second step ("Is this a reasonable interpretation?") as well as to the first step ("Did Congress speak to the question?") of the Cheuron process. ${ }^{165}$ Some commentators have stated that when the canon should be applied depends on whether it is a "statute-defining" canon or a "statute-applying" canon. ${ }^{168}$ If a court views a canon as statute-defining, it will use it during the first step of the Chevron process to remove any ambiguity in a statute. Thus, application of the canon that every word in a statute has independent meaning may make only one interpretation of a law possible. If a court views a canon as statute-applying, it will use it during the second step of the process to limit an agency's discretion. Thus, after considering the canon that exemptions from taxation are to be construed narrowly, a court might conclude that an agency has given an exemption an unreasonably broad interpretation.

The distinction between statute-applying and statute-defining canons does not appear to have played a role in the Supreme Court's jurisprudence. For example, the Court has shown a willingness to apply the canon that statutes should be interpreted so as to avoid constitutional problems to both Chevron steps. In DeBartolo, the Court used the canon on the first step, and determined that Congress had not granted the NLRB the power to prohibit handbilling. ${ }^{167}$ In Rust $v$ Sullivan, Justice O'Connor invoked the canon on the second step, arguing that regulations restricting the right of doctors in government-funded clinics to discuss abortions were unreasonable because they implicated constitutional rights. ${ }^{168}$

The canon favoring Indians can likewise be applied usefully at both levels. In some cases, its application will give a definitive answer to the first step. For example, when applied in Choate, the canon led to the conclusion that Congress had not repealed the tax exemption, and produced the result most favorable to the Native

\footnotetext{
${ }^{165}$ See Michigan Citizens for an Independent Press $v$ Thornburgh, 868 F2d 1285, 1292-93, 1299 n 6 (DC Cir 1989).

${ }^{188}$ Note, Chevron and Canons of Statutory Construction, 58 Geo Wash L Rev 829, 839-40 (1990). See also Clark Byse, Judicial Review of Administrative Interpretations of Statutes: An Analysis of Chevron's Step Two, 2 Admin L J 255, 261-66 (1988).

${ }^{167} 485$ US at 588.

${ }^{168} 111 \mathrm{~S}$ Ct 1759, 1789 (1991) (O'Connor dissenting).
} 
Americans. ${ }^{168}$ In other cases, the canon can be applied in the second step to narrow the range of possible interpretations. Thus, there may be two choices, both of which are arguably "most" favorable to Native Americans. The canon would have the court uphold an agency's choice of one of the favorable interpretations while requiring it to reject a less favorable alternative.

The commentators who make distinctions between types of canons argue that when applied to the second step, "statute-applying" canons (such as the canon favoring Indians) should be merely one of many factors looked at in determining whether the interpretation is reasonable. ${ }^{170}$ This argument is based on the notion that these canons are merely guides to applying a statute to particular facts. ${ }^{171}$ As argued above, the canon favoring Indians is more than just a guide. ${ }^{172}$ Therefore, it would be inappropriate for courts to limit the canon's influence when examining the reasonableness of an agency's interpretation.

\section{Conclusion}

Chevron is best understood as a shift in the Court's presumption concerning congressional intent. As a result of Chevron, the Court now presumes that Congress intends to delegate power to an agency when it drafts an ambiguous statute. This shift in presumption is justified by a certain conception of the relative competency and roles of the agencies and the judiciary. In particular, it is justified by the belief that agencies have greater expertise, that agencies are more accountable, and that courts do not have tools that are particularly useful in resolving the ambiguity.

Despite this presumption of deference, the Court still uses canons of statutory construction when interpreting statutes. Canons protect or promote certain values. Chevron explicitly calls for their application. However, in some instances, application of canons will be inconsistent with the factors motivating the presumption of delegation; given the new conception of the role and competency of courts, the values underlying the canons will be better protected by agencies than by courts.

The judiciary has long viewed the relationship between the United States and Native American tribes as one of wardship. The canon favoring Indians is one of several legal doctrines which pro-

\footnotetext{
160 See text accompanying notes 74-83.

170 Note, 58 Geo Wash I Rev at 841.

171 Id at 840 .

172 See text accompanying notes 129-30.
} 
tects and promotes that notion of wardship. The Court has considered that a broad and generous reading of statutes and treaties is the best way to advance the congressional wardship policy. In addition, the Court itself has taken on a special role in the wardship notion. It has assumed that Native Americans are vulnerable to exploitation by individuals, states, and the executive branch, and that courts should ensure that Native Americans are protected from such intrusions. Application of the canon is one of the primary tools courts use to complete that task.

A comparison of the factors motivating the presumption of deference and the values protected by the canon favoring Indians indicates that the courts should continue to apply the canon. To a certain extent, agencies' expertise might better enable them to carry out Congress's purposes regarding wardship, but there is also a danger that they will not give sufficient priority to Native American claims. As Native Americans are relatively powerless politically, the increased accountability of agencies will not enhance the protection of the notion of wardship. Furthermore, in contrast to other situations, the judiciary does have a special role to play in protecting the wardship relation. On balance it appears that judicial application of the canon will better protect the wardship relation than deference to agency interpretations. To be consistent with Chevron, therefore, courts should apply the canon favoring Indians. 